\title{
Performance Evaluation and Economic Analysis of Stepped Solar Still with Wire Mesh
}

\author{
Vaishally Dogra, Chandra Kishore, Deepak Verma
}

\begin{abstract}
Pure and distilled water is now serving as a basic daily necessity for human being functionality. Solar energy is widely being used for purifying the salt water with basic fundamental of evaporation and condensation through a solar still which captures the sunrays, evaporates the seawater, condensate the vapors and purifies the water. This method is the widely used green method for water distillation via set ups. This paper concentrates at water purification by modified stepped solar still with wire mesh and comparing it with a conventional still. Still with 4 steps with depth of $5 \mathrm{~mm}$ and $120 \mathrm{~mm}$ wide were fabricated on modified still. The efficiency of stepped stiller was altered up to $30.72 \%$ and the amount of distillate obtained was $1932 \mathrm{ml} / \mathrm{m}^{2} /$ day in case of conventional distillerand 2800 $\mathrm{ml} / \mathrm{m}^{2} /$ day was for stepped one.
\end{abstract}

Keywords: Stepped Solar Still, Efficiency, Flat Plate Collector, Economic Analysis, Distillation

\section{INTRODUCTION}

Solar distillation is one amongst the best renewable methods for purifying water by evaporating and condensing the brackish water via sunrays concentrating on the brackish water through a glass cover. Novel seawater solar desalination system with an integration of static collector based solar thermal field and multi-effect membrane distillation technology was simulated by (Manas et al.,2002) showing that annual range of distillate output ranged between 41.7 and $70.5 \mathrm{~m}^{3}$ and maximum for $35.9 \mathrm{~m}^{2}$ solar field. Economic and thermal performance of stepped double slope solar still in integration with linen wicks and carbon black nanoparticles was improved by (Sharshi et al.,2020) leading to increase in productivity of freshwater and exergy efficiency by 80.57 and $110.5 \%$ respectively. The fractional exergy of evaporation was highest when linen wicks were used on steps and nanoparticles in the basin saline water.

(Sharon et al., 2020)Viability assessed solar distillation used for desalination in coastal locations of Indian sub-continent with the help of mathematical model and results showed that yearly condensate production varied from 745.84 to 1346.38 L/Yr with energy efficiency of $44.06 \%$. Highest desired production of $3.38 \mathrm{kWh} / \mathrm{USD}$ was noticed for Porbandar and the lowest for Port Blair with $1.60 \mathrm{kWh} / \mathrm{USD}$. Simultaneous transfer of heat in hollow fiber membrane modules for sweeping gas membrane distillation unit was studied by (Gupoei et al., 2020) and a mathematical model was established in outdoor weather conditions for the same.

Revised Manuscript Received on August 10, 2019.

Vaishally Dogra*, P. HD. Scholar, Department of Mechanical Engineering, Graphic Era Hill University, Uttarakhand, India. E-mail vaishali.dogra@gmail.com

Dr. Chandra Kishore, Department of Mechanical engineering, Graphic Era Deemed to be University, Uttarakhand, India.

Deepak Verma, Department of Mechanical Engineering, Graphic Era Hill University, Uttarakhand, India.
Different parameters of membrane structure like pore size, porosity and tortuosity for the membrane pore were experimentally validated for the mathematical model with results stating that system performance was no longer raised for pore diameters above $150 \mathrm{~nm}$ with an optimal porosity of about 0.75 .

(Quiming et al.,2020) Designed a desalination unit on a small scale for drinki8ng water production in remote places with a simultaneous strategy of heat recovery and permeate condensation by heat pump and photovoltaic power capacity for per unit water production almost ranged between 4.2 to $5.0 \mathrm{~W} / \mathrm{L}$. Further results revealed that freshwater production of $3.7 \mathrm{~L}$ on daily basis for tiny module of $0.18 \mathrm{~m}^{2}$ with 17 Welectric consumption and for a large scale module of $3 \mathrm{~m}^{2} 96 \mathrm{~L}$ of freshwater consuming $449 \mathrm{~W}$.

A comparative study between modified stepped still containing black and cotton absorber with conventional still was performed (Agouz et al., 2014) leading to a conclusion that efficiency of stepped still was $20 \%$ more than basic one at water flow rate of 1 LPM and 3 LPM for sea water and salt water respectively.(Z.M.Omara et al., 2014) carried a study on stepped still with external and internal reflectors and indicated results showed that efficiency foe stepped still with reflectors was $125 \%$ more than conventional still. 11 of distilate costed approximately $0.031 \$$ for stepped still and $0.049 \$$ for conventional still.Experimental study of distance between evaporator and condensate of inclined multistage desalination plant was installed (Mirzaev et al., 2019)and results declared that maximum mass condensate occurred for 4 to $8 \mathrm{~cm}$ condensate and evaporator distance, $5.21 \mathrm{~cm}$ to be precise.

\section{Nomenclature}

$\alpha^{\prime}=$ fraction of solar flux absorbed

$I(t)=$ intensity of solar radiation over inclined surface of still $\left(\mathrm{W} / \mathrm{m}^{2}\right)$

$\mathrm{q}_{\mathrm{c}, \mathrm{w}-\mathrm{g}}=$ convective heat transfer rate from water to glass cover $\left(\mathrm{W} / \mathrm{m}^{2}\right)$

$\mathrm{q}_{\mathrm{e}, \mathrm{w}-\mathrm{g}}=$ evaporative heat transfer rate within still from water to glass cover $\left(\mathrm{W} / \mathrm{m}^{2}\right)$

$\mathrm{L}_{\mathrm{g}}=$ thickness of glass cover $(\mathrm{m})$

$\mathrm{K}_{\mathrm{g}}=$ thermal conductivity of glass cover $\left(\mathrm{W} / \mathrm{m}^{\circ} \mathrm{C}\right)$

$\mathrm{q}_{\mathrm{r}, \mathrm{g}-\mathrm{a}}=$ radiative heat transfer rate from glass cover to ambient $\left(\mathrm{W} / \mathrm{m}^{2}\right)$

$\mathrm{q}_{\mathrm{c}, \mathrm{g}-\mathrm{a}}=$ convective heat transfer rate from glass cover to ambient $\left(\mathrm{W} / \mathrm{m}^{2}\right)$

$\mathrm{q}_{\mathrm{b}}=$ heat transfer rate from basin liner to ambient $\left(\mathrm{W} / \mathrm{m}^{2}\right)$

$\mathrm{q}_{\mathrm{w}}=$ convective heat transfer rate from basin liner to ambient $\left(\mathrm{W} / \mathrm{m}^{2}\right)$

$\mathrm{m}_{\mathrm{ew}}=$ hourly output from solar still $\left(\mathrm{kg} / \mathrm{m}^{2} \mathrm{~h}\right)$

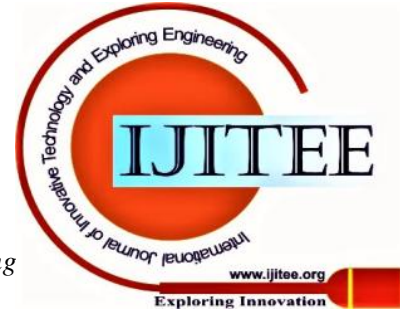




\section{Performance Evaluation and Economic Analysis of Stepped Solar Still with Wire Mesh}

$\mathrm{h}_{\mathrm{b}}=$ overall heat transfer coefficient from basin liner to ambient $\left(\mathrm{W} / \mathrm{m}^{2 \mathrm{o}} \mathrm{C}\right)$

$\mathrm{h}_{\mathrm{e}, \mathrm{w}-\mathrm{g}}=$ evaporative heat transfer coefficient from water to glass cover $\left(\mathrm{W} / \mathrm{m}^{2 \mathrm{o}} \mathrm{C}\right)$

$\mathrm{T}=$ temperature $\left({ }^{\circ} \mathrm{C}\right)$

$\mathrm{A}=\left(\mathrm{m}^{2}\right)$

$\mathrm{L}=$ latent heat of vaporization $(\mathrm{J} / \mathrm{kg})$

Subscripts

g glass

gi inner glass cover

go outer glass cover

b basin liner

w water

s solar still

c solar collector

\section{Greek}

$\eta \quad$ efficiency $(\%)$

Borosilicate vacuum tubes with heat pipes inside distiller was studied (Saetoone et al., 2017)for productivity enhancement for stepped still and was further compared with stepped still without vacuum tubes. Results proved that output distillate of freshwater was more in sunny days than and stepped still with vacuum tubes was $32.4 \%$ more enhanced to stepped still without vacuum tubes.

Evaluation of cost parameters with exergy and energy analysis was done by Ibrahim et al. (2017). In addition to this, key variable effect on exergoeconomic cost of freshwater production was also investigated and a graphical approach was used for the same. The results revealed that exergy destructions cost was decreased by $36 \%$ leading to $45 \%$ deduction in exergeconomic cost of the freshwater produced.

Ali.F.Muftah et al. (2018) integrated a superior design concepts like using internal reflectors, absorbers, etc. into one design and energy balance analysis for multiple parameters was conducted for the proposed model. Thermal performance was increased for modified stepped distiller and results led to $29 \%$ enhancement in the modified still for daily productivity. Sallami et al.(2017) aimed at improving solar still yield by improving the performance of absorber using an added inner heat storage system for which absorber surface was covered with layers of blackened sponge and then tested. The results depicted that yield was increased by $57.77 \%$ for a sponge thickness of $0.5 \mathrm{~cm}$ with no blackened sponge while sponge thickness of $1.5 \mathrm{~cm}$ showed that the yield decrease by $29.95 \%$.

A desalination complex based on wind energy marine units was suggested by V.V.Cheboxarov et al.(2019) and concluded that this particular unit partially solved the problem of water for the places which lack the centralized power supply.A stepped solar still of $1.8 \mathrm{~m}$ x $1.2 \mathrm{~m}$ x $0.20 \mathrm{~m}$ dimensions with a copper inclination containing 28 trays of $1.2 \mathrm{~m}$ length and $0.6 \mathrm{~m}$ height was fabricated (Abujazar et al., 2017)and results conveyed that the environmental parameters highly affected the still than operational ones which showed that best hourly efficiency was $58 \%$ approximately with $4383 \mathrm{~mL} / \mathrm{m}^{2}$ d.Experimental and numerical analysis was performed on stepped still coupled with photovoltaic thermal water collector (Naroei et al., 2018) taking into consideration the energy balance for different still components. End results unveiled that energy efficiency was two times more and freshwater productivity was elevated by an amount of $20 \%$. The photovoltaic water collector was able to additionally supply $1.06 \mathrm{~kW} /$ day electric powers.

Herrena et al. (2017)developed favorable designs for reactive distillation systems for producing trichlorosilane, dichlorosilane and silane. The system was developed and optimized problem was formulated for finding best common system structure with operating conditions of product and use of genetic algorithms as optimization tool was effective tool proved. The results depicted that there was only minor effect on steady state values of maximum production temperatures of three products.

Experimental investigation of solar thermal driven membrane distillation-based desalination system was carried out by Kabeel et al. (2017) leading to a system efficiency of $49.01 \%$ with increase in water mass flow rate and more air mass flow rate with a maximum productivity of 33.55 L/day. The gained output ration of the system reached to a value of 0.49 and the cooling unit used led to asignificant increase of almost 1.25 times in productivity to that without the use of cooling unit.

Performance study on a photovoltaic thermal stepped solar still with a bottom channel was done by Lan Xiao et al. (2019). A theoretical model was established and validated for the study and assessed results revealed that absorber plate to saline water heat transfer rate was altered by $44 \%$ for $0.01 \mathrm{~m}$ bottom channel depth leading to $51.7 \%$ increase in freshwater productivity. Similarly average thermal and exergy efficiency was escalated by $17 \%$ and $3 \%$ respectively.

Multi-Tray Evaporator was used as an additional evaporation area by integrating with rear wall of still (Saddi et al., 2018) to enhance daily productivity and was comparatively compared with conventional still with different meteorological conditions in Adrar-Algeria region. The modification led to a conclusion that productivity was about 47.18-104.73\% higher than for conventional still and estimated cost of distillate was $0.01 \$ / \mathrm{kg}$.

Radiation shape factor for hot saline water and glass cover for stepped type solar still for $10^{\circ}$ to $70^{\circ}$ inclination of glass cover and 200 to about $1200 \mathrm{~W} / \mathrm{m}^{2}$ solar insolationwas computed by Samadony et al.(2016)on still productivity and revealed that still productivity of $18.8 \%$ considering radiation shape factor was resulted for low insolation of 200 $\mathrm{W} / \mathrm{m}^{2}$ and $70^{\circ}$ glass cover inclination.

Different water depth with different sensible heat storage mediums such as wick, rock and sponge affecting the efficiency of stepped solar still adjoining with flat plate collector was analyzed and compared with conventional (Aalaudeen et al., 2014) which showed that maximum and minimum productivity was obtained respectively for $2 \mathrm{~cm}$ and $4 \mathrm{~cm}$ water depth. Wick and sponge combination in 2 $\mathrm{cm}$ water depth gave a maximum output of $1305 \mathrm{~kg} / \mathrm{m}^{2}$ and a payback of about 320 days was required for the stepped still. 
Al-Nimur et al. (2016) proposed a hybrid solar-wind distillation system consisting of conventional basin still and a simultaneous operative wind-water heater which led to a production of large output of distill water because of its operative ability at day and as well at night and on cloudy days too. Construction and simulation of simple model equations were done resulting in significant increase in output with three to four times more as compared to conventional stills.

A triangular solar still using cheap and durable materials was designed by Ehsan et al. (2014) and relationships between daily production amount, daily solar irradiation and initial water depth were attained by changing water depth with climatic conditions. Inverse relationship between production and water depth was seen and water quality parameters were within the accepted drinking water range.

Installation of reflective mirrors for stepped solar still wereinvestigated theoretically (Omara et al., 2013) which increased the thermal performance of modified still and was approximately $75 \%$ more productive with reflectors and $57 \%$ productive without reflectors when compared to conventional still. Modified stepped still was moreover 22\% more efficient than the conventional.V.Sivakumar et al. (2013) reviewed various efficiency improvement techniques for solar still and results showed that annual yield will be maximum for glass inclination angle same as place latitude and evacuated tube collector coupled with still led to $77 \%$ increase in productivity with comparison to conventional one. Also daily output was increased by $29 \%$ when black paint in basin liner was replaced by asphalt.Vacuum tube collector was used by A.E.Kabeel et al. (2012) for varying temperature of feed water to stepped still and studying the tray depth influence and width on still performance. The study revealed that maximum productivity about $57.3 \%$ higher was obtained for a tray of $5 \mathrm{~mm}$ depth and $120 \mathrm{~mm}$ wide than that in case of conventional still.Aayush Kaushal et. al. (2010) reviewed different solar stills and summarized that still efficiency can be enhanced by around $20 \%$ when cooling film parameters are properly combined and productivity decreases by $15 \%$ if diffusion gaps in multieffect diffusion model are increased from 5 to $10 \mathrm{~mm}$. Effluent settling tank was fabricated with a payback period of 727 days (Velmurugan et al., 2009) for desalinating textile effluent using them as raw material and performance analysis was carried out. 50 trays of two different depths were used for better performance and pebble, sponge and fin combination was used for increasing productivity. Results revealed that rates of production were increased by $53.3 \%$, $68 \%$ and $65 \%$ for fins, sponge and pebbles respectively. Combination of sponge and pebble in fin type stepped increased the productivity by $98 \%$ with reference to conventional still.

A new flat-sheet cross flow membrane module fitted with a hydrophobic polyvinylidene-fluoride (PVDF) microfiltration membrane was used by Manna et al. (2010) for removing the arsenic from contaminated groundwater and resulted that it produced almost 100 percent arsenic-free water. Resulted data showed that feed flow rate of $0.120 \mathrm{~m}^{3} / \mathrm{h}$ for $0.13 \mu \mathrm{M}$ PVDF membrane led to a yield of $74 \mathrm{~kg} / \mathrm{m}^{2} \mathrm{~h}$ of flux at $40^{\circ} \mathrm{C}$ feed water temperature and $95 \mathrm{~kg} / \mathrm{m}^{2} \mathrm{~h}$ for $60^{\circ} \mathrm{C}$ feed water temperature.Simulation calculations for the membrane distillation units with derived module characteristics from several experimental investigation for different potential installation units were done by Koschikowski et al. (2003) with results depicting that the simple compact system with collector area for less than $6 \mathrm{~m}^{2}$ without heat storage can give an output of 120 to $160 \mathrm{~L}$ in a day for summer in the southern country.

\section{EXPERIMENTAL DESIGN AND SETUP}

Two solar distillers, one conventional type, Fig.1, with a basin area of $1 \mathrm{~m}^{2}$ and other stepped type with wall heights of $450 \mathrm{~mm}$ on high-side and $610 \mathrm{~mm}$ on the other side, Fig.2, were constructed and their performance is compared.The effect of feed water temperature on the stepped solar still was examined by using flat plate solar collector,Fig.3.Galvanized steel sheets are used in fabrication of stills and coating of black paint is done for basin surface so that more amounts of solar radiations are absorbed. To reduce the side and bottom heat losses, sawdust is used for insulation. A $3 \mathrm{~mm}$ thick glass is used inclined at an angle of nearly $30^{\circ}$ horizontally, which is the latitude of Solan, Himachal Pradesh to raise the amount of insolation. Basin area of stepped is similar to conventional one and 5 steps of absorber plate each with size of $0.1 \mathrm{~m} \mathrm{x} 2$ $\mathrm{m}$ containing wire meshes are made. For temperature measurements of water and glass, Iron-constantan thermocouples are used at different places including absorber steps. A calibrated solar pyranometer is used for measuring global radiation, digital anemometer for wind velocity and a 2 litre capacity flask for collection of distillate. 
Performance Evaluation and Economic Analysis of Stepped Solar Still with Wire Mesh

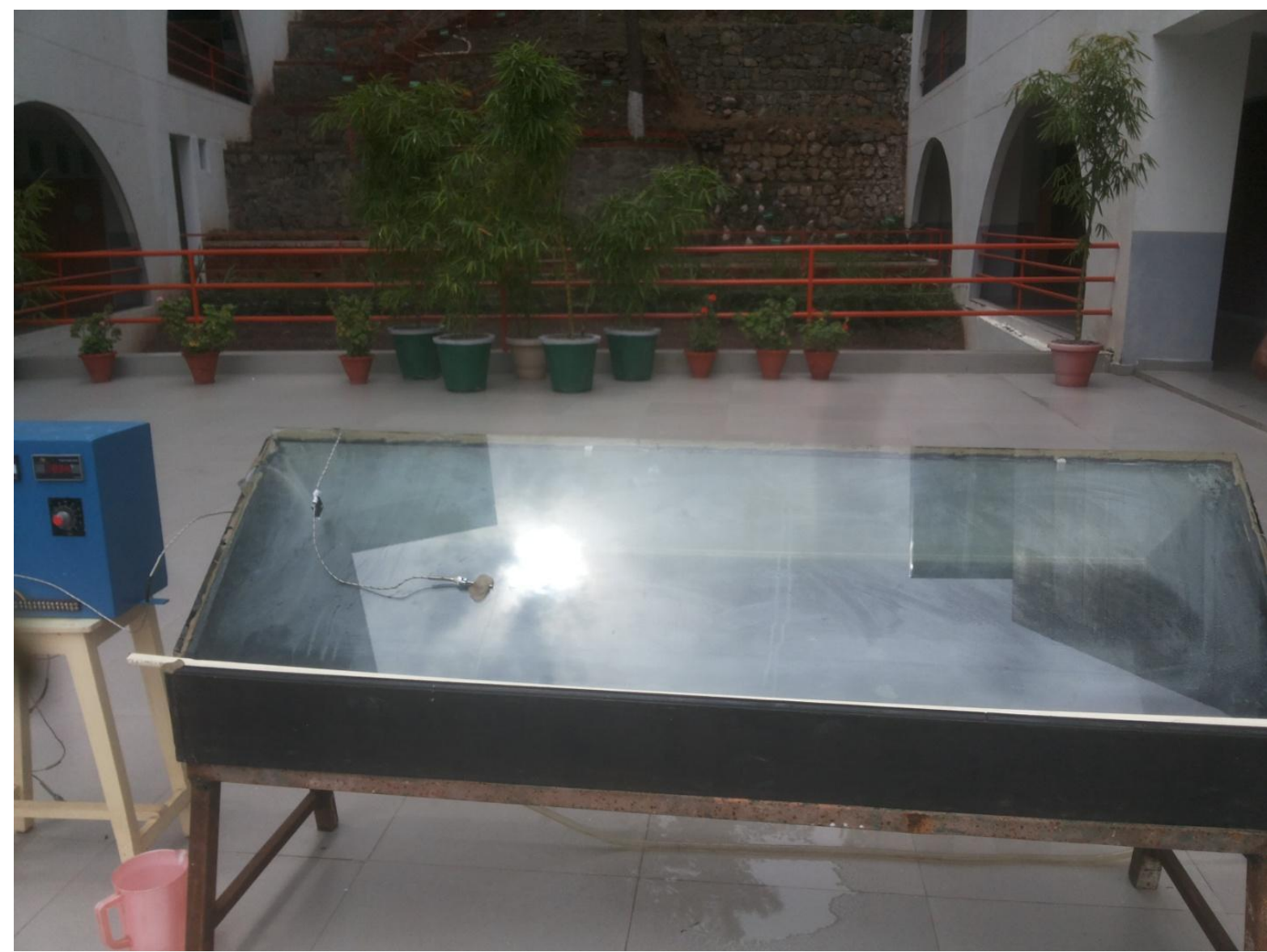

Fig.1. Conventional solar still

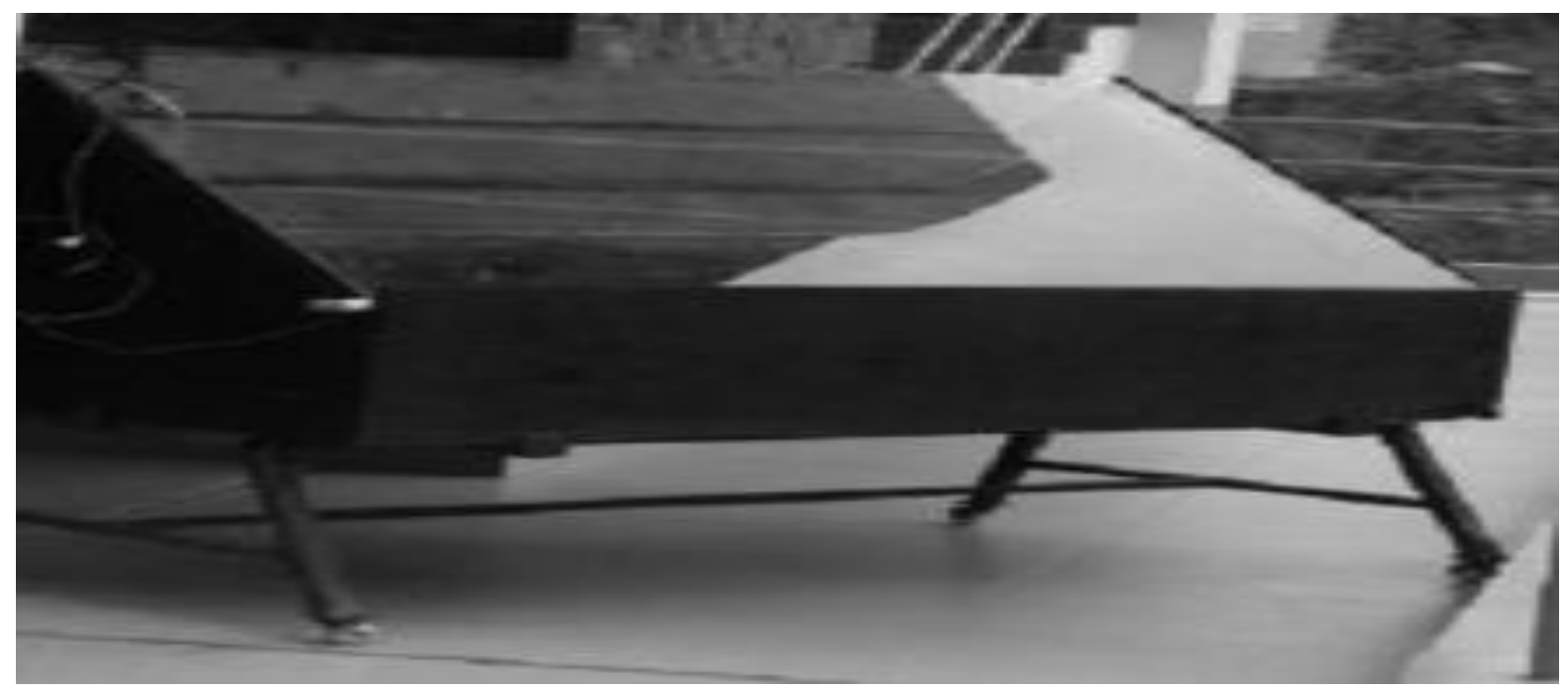

Fig.2 Stepped solar still

The experimental setup for stepped solar still comprises of the following specifications:

Wooden box $=2 \times 0.5 \mathrm{~m}^{2}$

Height of box at rear end $=0.61 \mathrm{~m}$

Height of box at front end $=0.4 \mathrm{~m}$

Gap between the sides of tray and wooden box $=$

$0.2 \mathrm{~m}$

Number of steps $=4$

Total area of tray $=240 \mathrm{~cm}^{2}$

Thickness of tray $=2 \mathrm{~mm}$

Tray depth $=5 \mathrm{~mm}$

Width of tray $=120 \mathrm{~mm}$

Thickness of glass cover $=9 \mathrm{~mm}$
Wire mesh $=4$ wire mesh of $(0.1 \mathrm{~m} \mathrm{x} 2 \mathrm{~m})$ for the steps and one wire mesh of $(2 \mathrm{~m} \times 0.5 \mathrm{~m})$ for basin

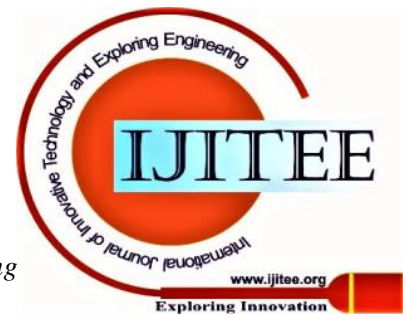




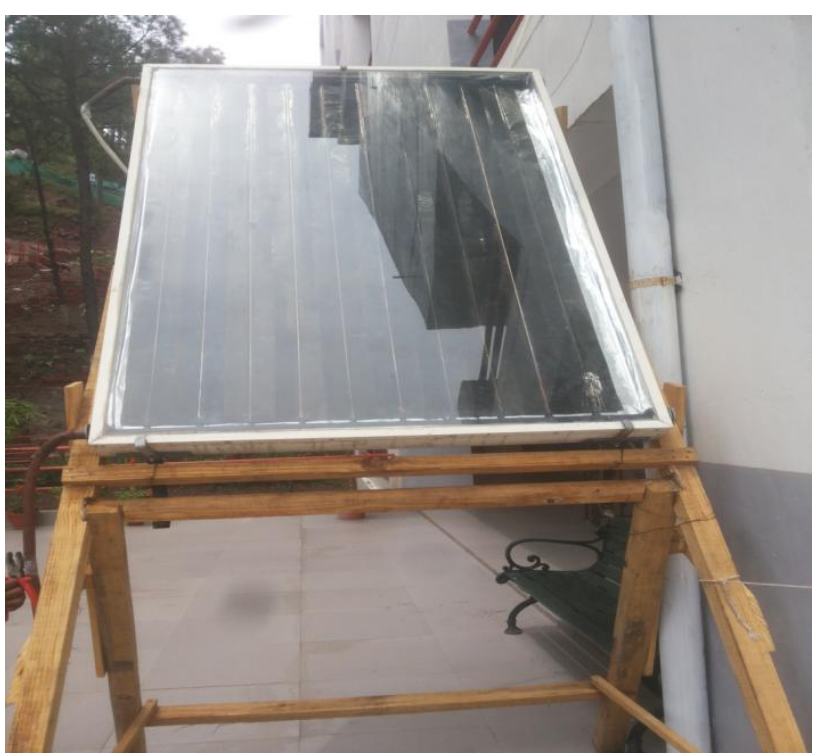

Fig.3 Flat Plate Collector

\section{EXPERIMENTAL PROCEDURE}

The conductionof experiment is done at the Department of Mechanical Engineering, Shoolini University, Solan, Himachal Pradesh. At an interval of thirty minutes, temperatures of saline water, basin plate, glass cover is measured with ambient temperature and solar insolation. Saline water depth is maintained the same for experiment and accumulated distillate is measure. Saline water affecting stepped still with wire mesh is investigated. The temperature effect of feed water on stepped distiller is investigated using flat plate collector.

\section{A. Instruments}

Standard calibrated and accurate instruments are used to capture the required data of Solar Irradiation, water temperature and glass cover temperature, $\mathrm{pH}$ of distillate yield output and wind velocity. Thermocouples, pyranometer, and anemometer are the accurate instruments used for collecting the experimental data. In addition water quality was checked before and after performing the experiment using a $\mathrm{pH}$ meter.

\section{B. Solar Radiation}

Intensity of solar radiation is one of the most important variable or factor in solar energy applications and needs to be measured very accurately and precisely for thermal testing in case of solar stills. In the performed experiment,Lutron Pyranometer, measuringthe solar radiation intensity ranging between $400-1500 \mathrm{~W} / \mathrm{m}^{2}$ is used.

\section{Temperature}

Iron-Constsntan thermocouples are used for measuring the temperature at different ends of both the conventional and stepped still. Different ends of the still for temperature measurement are basin water, outer glass cover andthe inner glass cover.

\section{Speed of surface wind}

Rate of loss of heat from still is influenced by the speed of wing and it needs to be measure at the utmost. As the experiment is ground-based, so anemometer with $1^{\circ} \mathrm{C} / 1.8^{\circ} \mathrm{F}$ air temperature acuuracy, $0.1^{\circ} \mathrm{C} / 0.1^{\circ} \mathrm{F}$ air temperature resolution and air velocity ranging between 0.3 to $90.0 \mathrm{~km} / \mathrm{h}$ is used.

Table.1 Characteristics of Anemometer

\begin{tabular}{|c|c|c|c|}
\hline Air Velocity & Range & Resolution & Accuracy \\
\hline $\mathrm{m} / \mathrm{s}$ & $\begin{array}{c}0.1 \text { to } \\
25.0 \mathrm{~m} / \mathrm{s}\end{array}$ & $0.01 \mathrm{~m} / \mathrm{s}$ & $\begin{array}{c} \pm 5 \% \\
\pm 0.1 \mathrm{~m} / \mathrm{s}\end{array}$ \\
\hline $\mathrm{km} / \mathrm{h}$ & $\begin{array}{c}0.3 \text { to } \\
90.0 \mathrm{~km} / \mathrm{h}\end{array}$ & $0.1 \mathrm{~km} / \mathrm{h}$ & $\begin{array}{c} \pm 5 \% \\
\pm 0.1 \mathrm{~km} / \mathrm{h}\end{array}$ \\
\hline $\mathrm{ft} / \mathrm{min}$ & $\begin{array}{c}20 \text { to } \\
4925 \mathrm{ft} / \mathrm{min}\end{array}$ & $1 \mathrm{ft} / \mathrm{min}$ & $\begin{array}{c} \pm 5 \% \\
\pm 1 \mathrm{ft} / \mathrm{min}\end{array}$ \\
\hline $\mathrm{MPH}$ & $\begin{array}{c}0.2 \text { to } \\
55.8 \mathrm{MPH}\end{array}$ & $0.1 \mathrm{MPH}$ & $\begin{array}{c} \pm 5 \% \\
\pm 0.1 \mathrm{MPH}\end{array}$ \\
\hline $\mathrm{Knots}$ & $\begin{array}{c}0.2 \text { to } \\
48.5 \mathrm{knots}\end{array}$ & $0.1 \mathrm{knots}$ & $\begin{array}{c} \pm 5 \% \\
\pm 0.1 \mathrm{knots}\end{array}$ \\
\hline Air & $\begin{array}{c}0^{\circ} \mathrm{C} \text { to } 50^{\circ} \mathrm{C} \\
32^{\circ} \mathrm{F} \text { to } \\
122^{\circ} \mathrm{F}\end{array}$ & $0.1^{\circ} \mathrm{C} / 0.1^{\circ} \mathrm{F}$ & $1^{\circ} \mathrm{C} / 1.8^{\circ} \mathrm{F}$ \\
\hline Temperature & \multicolumn{2}{|c}{} & \\
\hline
\end{tabular}

\section{E. Quality of water}

Quality of water before and after distillation needs to be measured and this was done by the $\mathrm{pH}$ meter with an operational range of 0-13.99 and accuracy of \pm 0.02 .

Table2. Instruments used during experimentation

\begin{tabular}{|c|c|c|c|}
\hline Parameter & $\begin{array}{l}\text { Instrument/ } \\
\text { Equipment }\end{array}$ & Model & $\begin{array}{c}\text { Accur } \\
\text { acy }\end{array}$ \\
\hline $\begin{array}{l}\text { Solar } \\
\text { Intensity }\end{array}$ & Pyranometer & $\begin{array}{c}\text { Model CMP-3, } \\
\text { Kipp and Zonen } \\
\text { BV, } \\
\text { Rontgenweg, } \\
\text { Holland (10- } \\
1500 \mathrm{~W} / \mathrm{m} 2)\end{array}$ & $\begin{array}{l} \pm 0.5 \\
\mathrm{~W} / \mathrm{m}^{2}\end{array}$ \\
\hline $\begin{array}{c}\text { Temperatur } \\
\mathrm{e} \\
\end{array}$ & $\begin{array}{c}\text { Thermocoupl } \\
\text { e } \\
\end{array}$ & $\begin{array}{c}\text { Iron-constsntan } \\
\text { (type J) }\end{array}$ & $\begin{array}{c} \pm 0.75 \\
\% \\
\end{array}$ \\
\hline $\begin{array}{c}\text { Surface } \\
\text { wind speed }\end{array}$ & Anemometer & $\begin{array}{c}\text { Model AV6, } 100 \\
\text { mm Hg, Air } \\
\text { Flow } \\
\text { Instruments, } \\
\text { England: Range: } \\
0-30 \mathrm{~m} / \mathrm{s}\end{array}$ & $\begin{array}{c} \pm 0.01 \\
\mathrm{~m} / \mathrm{s}\end{array}$ \\
\hline $\begin{array}{l}\text { Quality of } \\
\text { water }\end{array}$ & $\mathrm{pH}$ meter & PCE-PH 22 & $\begin{array}{c} \pm 0.02 \\
\mathrm{pH}\end{array}$ \\
\hline
\end{tabular}

\section{THEORETICAL ANALYSIS}

Energy balance equation for still as given by Tiware et al. (2009) are:

For inner glass cover, eq.(1)

$\alpha_{\mathrm{g}}^{\prime} \mathrm{I}(\mathrm{t})_{\mathrm{s}}+\mathrm{q}_{\mathrm{r}, \mathrm{w}-\mathrm{g}}+\mathrm{q}_{\mathrm{c}, \mathrm{w}-\mathrm{g}}+\mathrm{q}_{\mathrm{e}, \mathrm{w}-\mathrm{g}}=\frac{\mathrm{K}_{\mathrm{g}}}{\mathrm{L}_{\mathrm{g}}}\left(\mathrm{T}_{\mathrm{gi}}-\mathrm{T}_{\mathrm{go}}\right)$

For outer glass cover, eq.(2)

$\frac{\mathrm{K}_{\mathrm{g}}}{\mathrm{L}_{\mathrm{g}}}\left(\mathrm{T}_{\mathrm{gi}}-\mathrm{T}_{\mathrm{go}}\right)=\mathrm{q}_{\mathrm{r}, \mathrm{g}-\mathrm{a}}+\mathrm{q}_{\mathrm{c}, \mathrm{g}-\mathrm{a}}$

For basin liner

$\alpha_{\mathrm{b}}^{\prime}\left(1-\alpha_{\mathrm{g}}^{\prime}\right)\left(1-\alpha_{\mathrm{w}}^{\prime}\right) \mathrm{I}(\mathrm{t})_{\mathrm{s}}=\mathrm{q}_{\mathrm{w}}+\mathrm{q}_{\mathrm{b}}$

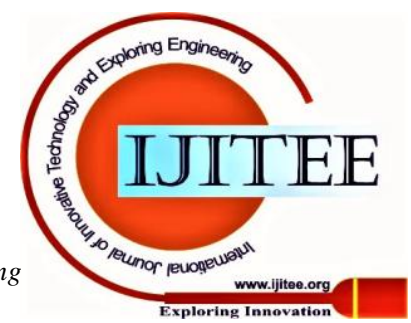


Internal heat transfer rates for still inculcates the $\mathrm{q}_{\mathrm{t}, \mathrm{g}-\mathrm{a}}=\mathrm{h}_{\mathrm{t}, \mathrm{g}-\mathrm{a}}\left(\mathrm{T}_{\mathrm{go}}-\mathrm{T}_{\mathrm{a}}\right)$

following equations (Tiwari et al., 2008):

$\mathrm{q}_{\mathrm{r}, \mathrm{w}-\mathrm{g}}=\mathrm{h}_{\mathrm{r}, \mathrm{w}-\mathrm{g}}\left(\mathrm{T}_{\mathrm{w}}-\mathrm{T}_{\mathrm{gi}}\right) \quad \mathrm{q}_{\mathrm{b}}=\mathrm{h}_{\mathrm{b}}\left(\mathrm{T}_{\mathrm{b}}-\mathrm{T}_{\mathrm{a}}\right)$

$\mathrm{q}_{\mathrm{c}, \mathrm{w}-\mathrm{g}}=\mathrm{h}_{\mathrm{c}, \mathrm{w}-\mathrm{g}}\left(\mathrm{T}_{\mathrm{w}}-\mathrm{T}_{\mathrm{gi}}\right)$

$\mathrm{q}_{\mathrm{e}, \mathrm{w}-\mathrm{g}}=\mathrm{h}_{\mathrm{e}, \mathrm{w}-\mathrm{g}}\left(\mathrm{T}_{\mathrm{w}}-\mathrm{T}_{\mathrm{gi}}\right)$

External rate of heat transfers which includes bottom and top heat transfer lossesoccurs as follows (Badran et al., 2007):

Hourly output distillate is calculated by

$\mathrm{m}_{\mathrm{ew}}=\frac{\mathrm{h}_{\mathrm{e}, \mathrm{w}-\mathrm{g}}\left(\mathrm{T}_{\mathrm{w}}-\mathrm{T}_{\mathrm{gi}}\right)}{\mathrm{L}} \times 3600 \times \mathrm{A}_{\mathrm{s}}$

Thermal efficiency for the stills is calculated by eq. (5):-

$\eta=\frac{m_{e w} \times L}{I(t)_{s} \times A}$

\section{RESULTS AND DISCUSSION}

A. Meteorological Data

Table 3. Meteorological data collected

\begin{tabular}{|c|c|c|c|c|c|c|c|c|}
\hline \multirow[t]{2}{*}{ Test day } & \multirow[t]{2}{*}{$\begin{array}{l}\text { Time } \\
\text { (h) }\end{array}$} & \multirow[t]{2}{*}{$\begin{array}{l}\text { Ambient } \\
\text { air Temp. } \\
\qquad\left({ }^{\circ} \mathbf{C}\right)\end{array}$} & \multirow[t]{2}{*}{$\begin{array}{c}\text { Solar } \\
\text { Irradiance } \\
\left(\mathbf{W} / \mathbf{m}^{2}\right)\end{array}$} & \multirow[t]{2}{*}{$\begin{array}{c}\text { Feed } \\
\text { water } \\
\text { Temp. } \\
\left({ }^{\circ} \mathbf{C}\right)\end{array}$} & \multicolumn{2}{|c|}{$\begin{array}{c}\text { Temp. of outer glass } \\
\text { cover } \\
\left(\mathbf{T}_{\mathrm{go}_{\mathrm{o}}}\right) \\
\end{array}$} & \multicolumn{2}{|c|}{$\begin{array}{c}\text { Temp. of inner glass } \\
\text { cover } \\
\left(\mathbf{T}_{\mathrm{g} i}\right) \\
\end{array}$} \\
\hline & & & & & Stepped & Conventional & Stepped & Conventional \\
\hline \multirow[t]{9}{*}{$6 / 7 / 2019$} & $10: 30 \mathrm{AM}$ & 30.4 & 708 & 72 & 36 & 35 & 37 & 38 \\
\hline & $11.00 \mathrm{AM}$ & 31.6 & 698 & 63 & 39 & 37 & 39 & 39 \\
\hline & $11.30 \mathrm{AM}$ & 29.5 & 678 & 60 & 38 & 35 & 42 & 41 \\
\hline & $12.00 \mathrm{AM}$ & 31.5 & 867 & 83 & 44 & 41 & 48 & 45 \\
\hline & $12.30 \mathrm{AM}$ & 34.5 & 809 & 80 & 42 & 40 & 45 & 43 \\
\hline & $1.00 \mathrm{PM}$ & 32.6 & 799 & 79 & 42 & 38 & 43 & 40 \\
\hline & $1.30 \mathrm{PM}$ & 31.9 & 764 & 72 & 41 & 36 & 40 & 39 \\
\hline & $2.00 \mathrm{PM}$ & 29.4 & 646 & 68 & 40 & 39 & 39 & 37 \\
\hline & $2.30 \mathrm{PM}$ & 29.9 & 523 & 53 & 38 & 37 & 37 & 35 \\
\hline \multirow[t]{9}{*}{$7 / 7 / 2019$} & $10.30 \mathrm{AM}$ & 29.6 & 990 & 89 & 44 & 40 & 46 & 44 \\
\hline & $11.00 \mathrm{AM}$ & 27.6 & 325 & 40 & 32 & 31 & 39 & 36 \\
\hline & $11.30 \mathrm{AM}$ & 30.5 & 590 & 58 & 33 & 34 & 47 & 45 \\
\hline & $12.00 \mathrm{AM}$ & 29.4 & 482 & 41 & 32 & 30 & 41 & 39 \\
\hline & $12.30 \mathrm{AM}$ & 31.9 & 906 & 85 & 42 & 40 & 44 & 42 \\
\hline & $1.00 \mathrm{PM}$ & 29.2 & 232 & 39 & 31 & 31 & 32 & 30 \\
\hline & $1.30 \mathrm{PM}$ & 27.9 & 365 & 45 & 30 & 29 & 32 & 31 \\
\hline & $2.00 \mathrm{PM}$ & 24.4 & 206 & 33 & 29 & 28 & 29 & 27 \\
\hline & $2.30 \mathrm{PM}$ & 26.8 & 780 & 75 & 35 & 32 & 39 & 37 \\
\hline \multirow[t]{9}{*}{$8 / 7 / 2019$} & $10.30 \mathrm{AM}$ & 27.8 & 899 & 84 & 41 & 39 & 44 & 42 \\
\hline & $11.00 \mathrm{AM}$ & 25.4 & 423 & 41 & 33 & 31 & 38 & 37 \\
\hline & $11.30 \mathrm{AM}$ & 30.1 & 509 & 56 & 35 & 33 & 40 & 39 \\
\hline & $12.00 \mathrm{AM}$ & 27.7 & 497 & 43 & 39 & 36 & 46 & 42 \\
\hline & $12.30 \mathrm{AM}$ & 30.2 & 997 & 90 & 42 & 40 & 46 & 44 \\
\hline & $1.00 \mathrm{PM}$ & 27.9 & 254 & 31 & 29 & 27 & 32 & 30 \\
\hline & $1.30 \mathrm{PM}$ & 26.6 & 401 & 40 & 32 & 30 & 41 & 40 \\
\hline & $2.00 \mathrm{PM}$ & 25.6 & 303 & 35 & 33 & 31 & 40 & 39 \\
\hline & $2.30 \mathrm{PM}$ & 27.1 & 769 & 74 & 36 & 34 & 42 & 41 \\
\hline \multirow[t]{5}{*}{ 9/7/2019 } & $10.30 \mathrm{AM}$ & 31.1 & 509 & 51 & 37 & 36 & 39 & 38 \\
\hline & $11.00 \mathrm{AM}$ & 30.5 & 599 & 59 & 40 & 39 & 40 & 40 \\
\hline & $11.30 \mathrm{AM}$ & 29.9 & 610 & 58 & 42 & 41 & 43 & 42 \\
\hline & $12.00 \mathrm{AM}$ & 30.4 & 765 & 74 & 40 & 39 & 42 & 41 \\
\hline & $12.30 \mathrm{AM}$ & 33.7 & 929 & 87 & 43 & 42 & 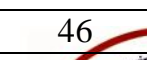 & 44 \\
\hline
\end{tabular}


International Journal of Innovative Technology and Exploring Engineering (IJITEE) ISSN: 2278-3075, Volume-8 Issue-10S2, August 2019

\begin{tabular}{|l|c|c|c|c|c|c|c|c|}
\hline & $1.00 \mathrm{PM}$ & 31.8 & 831 & 80 & 40 & 39 & 43 & 40 \\
\hline & $1.30 \mathrm{PM}$ & 29.9 & 856 & 82 & 41 & 38 & 42 & 41 \\
\hline & $2.00 \mathrm{PM}$ & 28.4 & 812 & 81 & 40 & 37 & 38 & 37 \\
\hline & $2.30 \mathrm{PM}$ & 30.9 & 734 & 74 & 39 & 39 & 37 & 34 \\
\hline $10 / 7 / 2019$ & $10.30 \mathrm{AM}$ & 27.1 & 476 & 49 & 36 & 35 & 37 & 35 \\
\hline & $11.00 \mathrm{AM}$ & 27.6 & 567 & 50 & 40 & 39 & 39 & 37 \\
\hline & $11.30 \mathrm{AM}$ & 28.9 & 613 & 59 & 42 & 41 & 40 & 40 \\
\hline & $12.00 \mathrm{AM}$ & 29.4 & 891 & 84 & 41 & 39 & 38 & 41 \\
\hline & $12.30 \mathrm{AM}$ & 31.8 & 903 & 86 & 44 & 43 & 46 & 45 \\
\hline & $1.00 \mathrm{PM}$ & 31.8 & 845 & 83 & 42 & 40 & 43 & 41 \\
\hline & $1.30 \mathrm{PM}$ & 30.5 & 674 & 61 & 41 & 40 & 41 & 41 \\
\hline & $2.00 \mathrm{PM}$ & 29.4 & 532 & 50 & 42 & 40 & 37 & 40 \\
\hline & $2.30 \mathrm{PM}$ & 31.9 & 435 & 49 & 40 & 36 & 39 & 38 \\
\hline
\end{tabular}

B. Accumulated productivity of some days

Table 4. Data for daily productivity of conventional and stepped still

\begin{tabular}{|c|c|c|c|}
\hline \multirow{2}{*}{ Date } & \multicolumn{2}{|c|}{$\begin{array}{c}\text { Daily Productivity } \\
\left(\mathbf{m l} / \mathbf{m}^{\mathbf{2}} / \mathbf{d a y}\right)\end{array}$} & \multirow{2}{*}{$\begin{array}{c}\text { Daily } \\
\text { productivity } \\
\text { rise (\%) }\end{array}$} \\
\cline { 2 - 3 } & $\begin{array}{c}\text { Conventional } \\
\text { Solar Still }\end{array}$ & $\begin{array}{c}\text { Stepped } \\
\text { Solar still } \\
\text { with mesh }\end{array}$ & \\
\hline $6 / 7 / 2019$ & 1501 & 1700 & 13.25 \\
\hline $7 / 7 / 2019$ & 1932 & 2800 & 3.52 \\
\hline $8 / 7 / 2019$ & 2056 & 2152 & 4.66 \\
\hline $9 / 7 / 2019$ & 1417 & 1610 & 13.62 \\
\hline $10 / 7 / 2019$ & 1312 & 1362 & 3.81 \\
\hline
\end{tabular}

Fig. 4 shows that the daily productivity rise is more in case of stepped still with mesh as compared to that of the conventional solar still.

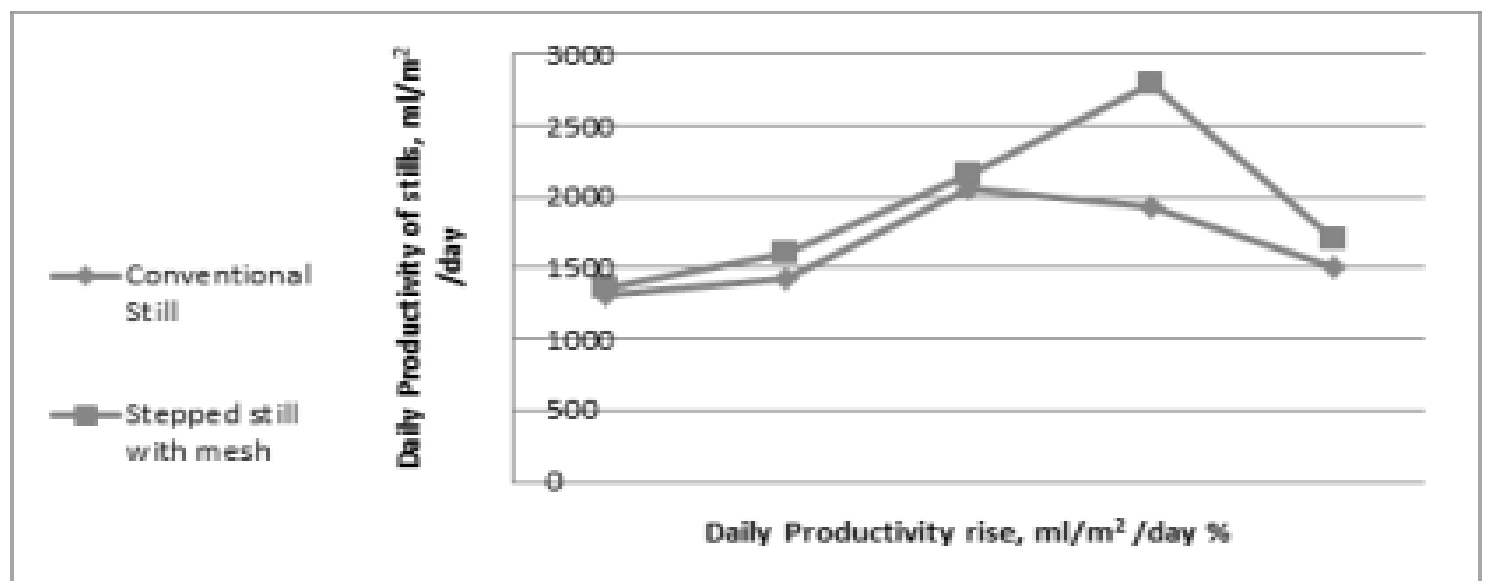

Fig.4. Daily productivity of stepped and conventional solar stills

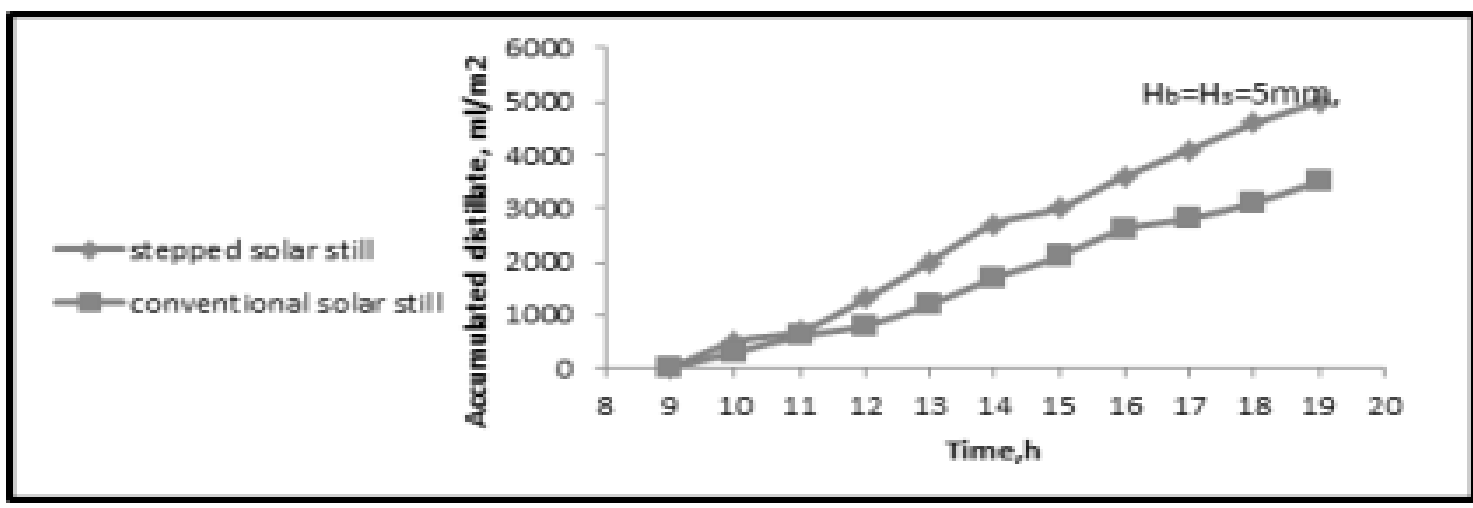

Fig.5. The accumulative variation of fresh water for the stepped and the conventional still for feed water temperature of $60^{\circ} \mathrm{C}$

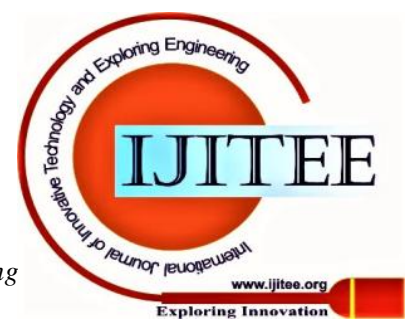




\section{Performance Evaluation and Economic Analysis of Stepped Solar Still with Wire Mesh}

Fig.5.displays that production rate on daily basis reached approximately 3200 and $4900 \mathrm{ml} / \mathrm{m}^{2} /$ day respectively for conventional and stepped stillwhich further reveals that distillate production of stepped still is $53.12 \%$ higher than conventional desalination unit.

\section{Daily efficiency of the stills}

Daily efficiencies of both the stills is calculated by the following equation-

Where, $\mathrm{m}$ is the mass of the accumulated distillate, $\mathrm{L}$ is latent heat of vaporization, $\mathrm{k} \mathrm{cal} / \mathrm{kg}$, I is intensity of solar radiation, $\mathrm{W} / \mathrm{m}^{2} /$ day and $\mathrm{A}$ is area of the basin of still. The value of latent heat of vaporization of water is taken as $594.5 \mathrm{kcal} / \mathrm{kg}$.
Table 5. Data showing daily efficiency of conventional and stepped still

\begin{tabular}{|l|l|l|l|}
\hline \multirow{2}{*}{ Date } & \multicolumn{2}{|l|}{ Daily Efficiency, \% } & Intensity of \\
\cline { 2 - 4 } & $\begin{array}{l}\text { Conventional } \\
\text { Still }\end{array}$ & $\begin{array}{l}\text { Stepped } \\
\text { still with } \\
\text { mesh }\end{array}$ & $\begin{array}{l}\text { radiation } \\
\left(\mathbf{W} / \mathbf{m}^{2}\right)\end{array}$ \\
\hline $6 / 7 / 2019$ & 17.95 & 20.3 & 497 \\
\hline $7 / 7 / 2019$ & 21.19 & 30.72 & 541.8 \\
\hline $8 / 7 / 2019$ & 37.4 & 39.2 & 326 \\
\hline $9 / 7 / 2019$ & 17.19 & 19.53 & 490 \\
\hline $10 / 7 / 2019$ & 19.94 & 20.7 & 391 \\
\hline
\end{tabular}

Fig. 6 shows the variation of daily efficiencies of the stills for some particular days with variation in solar irradiance. From this figure it is found that the maximum efficiency is for the maximum solar radiation on 7 July,2019 with maximum efficiency of $30.72 \%$ for stepped solar still with mesh and $21.19 \%$ for conventional still with solar radiation of $541.8 \mathrm{~W} / \mathrm{m}^{2}$.

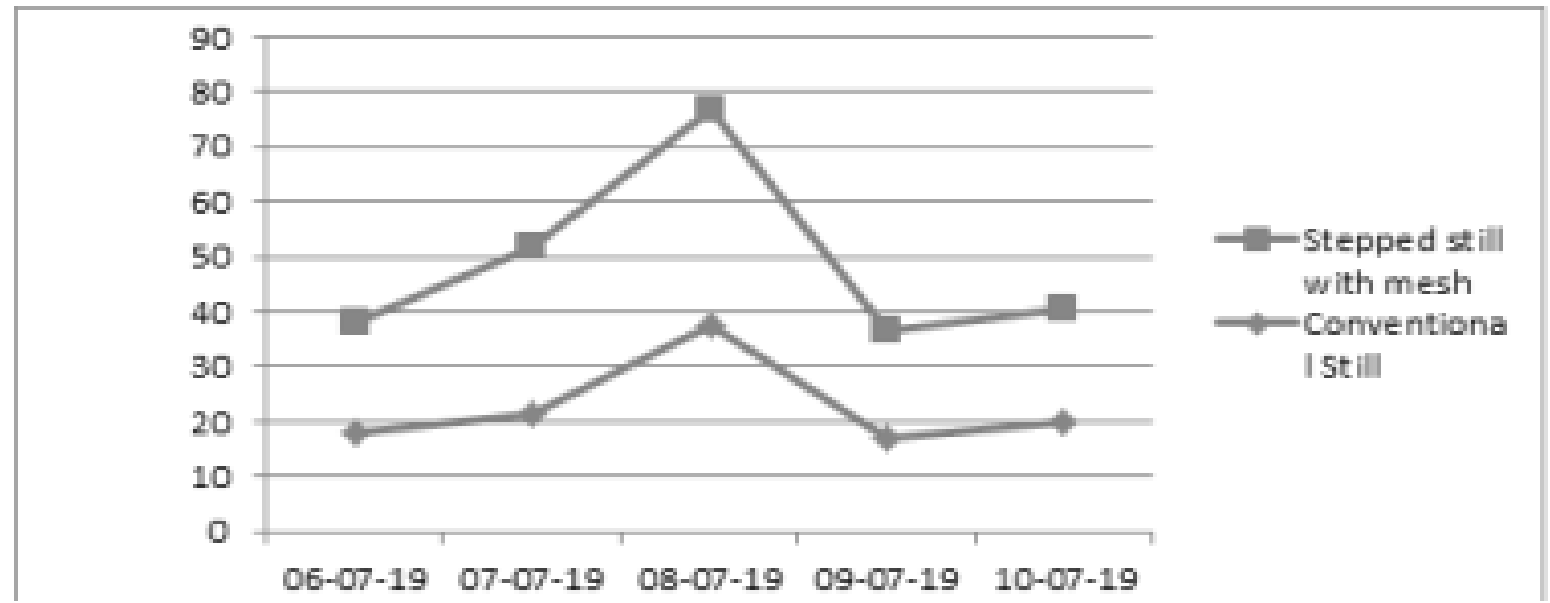

Fig.6 Variation of daily efficiencies of conventional and stepped stills with varying solar radiations

Fig.7 shows the variation between temperature, time and solar radiation and indicates that solar radiation and temperature has a maximum value at the noon time and starts decreasing after that.

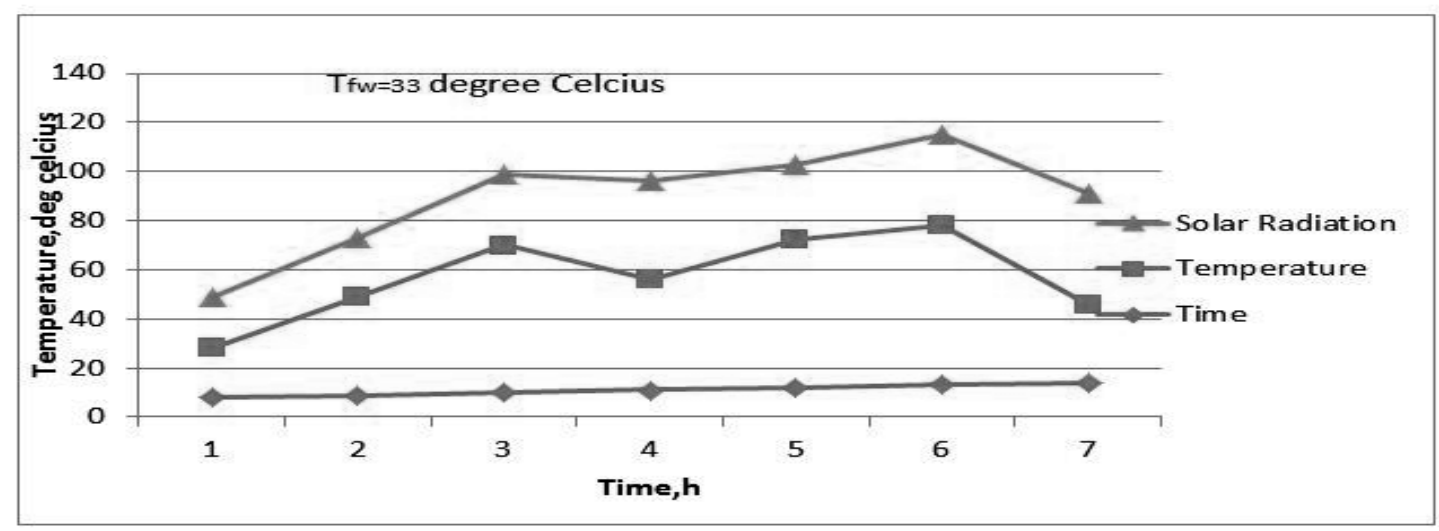

Fig7. Variation between temperature $\left({ }^{\circ} \mathrm{C}\right)$, Time $(\mathrm{h})$ and Solar radiation $\left(\mathrm{W} / \mathrm{m}^{2}\right)$ 


\section{D. pH of sample and the distilled water}

A sample of the distilled water was tested in the laboratory at the Biotechnology department, Shoolini University. The testing parameters were $\mathrm{pH}$ and salinity $\mathrm{pH}$ measure was made with $\mathrm{pH}$ meter.

Table 6. Distilled Water Analysis

\begin{tabular}{|c|c|c|c|}
\hline & $\begin{array}{c}\text { Sample } \\
\text { Water }\end{array}$ & $\begin{array}{c}\text { Distilled } \\
\text { Water }\end{array}$ & $\begin{array}{c}\text { Drinking } \\
\text { Water } \\
\text { Standards }\end{array}$ \\
\hline $\mathrm{pH}$ & 8.4 & 8.0 & $6.5-9.2$ \\
\hline Salinity & 0.2 & 0.15 & $<0.25$ \\
\hline
\end{tabular}

The $\mathrm{pH}$ of water sample that was to be distilled was 8.4 before distillation experiment and afterwards was 8.0 which lie in the drinking water standards range. Also the salinity was reduced from 0.2 to 0.15 and which ranges in standards.

\section{E. Economic analysis}

Payback period for stepped solar distiller was calculated as follows including the cost of fabrication, maintenance, operation.

Overall cost of fabrication $=$ Rs. 18,000

Per litre distilled water cost $=$ Rs. 10

Solar still (considering maximum) productivity $=2.8$ $1 / \mathrm{m}^{2} /$ day

Per day cost of water produced $=$ Rs. 28

Cost of maintenance $=$ Rs. $5 /$ day

Net earning $=$ Per day cost of water produced - Cost of maintenance

$$
\begin{aligned}
& =\text { Rs. }(28-5) \\
& =\text { Rs. } 23
\end{aligned}
$$

Payback period $=$ Investment $/$ Net earning

$$
\begin{aligned}
& =18,000 / 23 \\
& =782 \text { days }
\end{aligned}
$$

\section{CONCLUSION}

In this work, the experimental results are obtained and the effect of wire mesh on the still productivity has been contrived and following points can be concluded according to the performed experiment:

- Wire mesh was also painted black so that moreamount of solar irradiation is absorbed by the water thus elevating the absorption rate.

- Productivity for the still was inflated at the point where solar insolation was maximum.

- Maximum solar insolation of $541.8 \mathrm{~W} / \mathrm{m}^{2}$ was observed on 07.07.20219 which resulted in maximum amount of distillate on the particular day.

- The wire mesh used in the stepped solar still hiked daily efficiency up to $30.72 \%$.

- The maximum amount of distillate obtained as on 07.07.2019 are $1932 \mathrm{ml} / \mathrm{m}^{2} /$ day for conventional and $2800 \mathrm{ml} / \mathrm{m}^{2} /$ day in case of stepped solar still.

- $\quad$ Payback period for stepped still was calculated as 782 days with overall fabrication cost amounting to Rs. 18000 .

\section{REFERENCES}

1. J.A.Andres-Manas, L.Roca, A.Ruiz-Augirre, F.G.Acien, J.D.Gil, G.Zaragoza, Application of solar energy, to seawater desalination in a pilot system based on vacuum multi-effect membrane distillation, Applied Energy 258 (2020) 114068

2. Swellam W. Sharshi, Mohamed A. Etawil, Almoataz M. Algazzar, Ravishankar Sathyamurthy, A.W.Kandeal, Performance enhancement of stepped double slope solar still by using nanoparticles and linen wicks: Exergy, energy and economic analysis, Applied Thermal Energy (2020) https://doi.org/10.1016/j.applthermaleng.2020.115278

3. H.Sharon, K.S.Reddy, D.Krithika, Ligy Philip, Viability assessment of solar distillation in coastal locations of Indian sub-continent Thermodynamic, condensate quality and environment aspects, Solar Energy 197 (2020) 84-98

4. Gupoei Li, Lin Lu, Li-zhi Zhang, System-scale modeling and membrane structure parameter optimization for solar-powered sweeping gas membrane distillation desalination system, Journal of Cleaner Production 253 (2020) 119968

5. Quiming Ma, Aras Ahmadi, Corinne Cabassud, Optimization and design of a novel small-scale integrated vacuum membrane distillation- solar flat-plate collector module with heat recovery strategy through heat pumps, Desalination 478 (2020) 114285

6. S.A.El-Agouz, Experimental investigation of stepped solar still with continuous water circulation, Energy Conversion and Management 86 (2014) 186-193.

7. Z.M.Omara, A.E.Kabeel, M.M.Younes, Enhancing the stepped solar still performance using internal and external reflectors, Energy Conversion and Management 78 (2014) 876-881

8. M.S.Mirzaev, K.A.Samiev, Sh.M.Mirzaev, Experimental Study of Distance between Evaporator and Condensate of Inclined Multistage Desalination Plant, Applied Solar Energy, 2019, vol. 55, pp. 41-48

9. Erich Saettone, Yohan Valencia-Tovar, Alberto Gomez-de-la-TorreGastello, Preliminary overview and evaluation of a steppes solar distiller with internal reflective walls and borosilicate vacuum tubes, Desalination 413 (2017) 136-143

10. Ayman G.M.Ibrahim, Ahmed M.Rashad, Ibrahim Dincer, Exergoeconomic analysis for cost optimization of a solar distillation system,Solar Energy, Volume 151, 2017, 22-32

11. Ali.F.Muftah, K. Sopian, M.A.Alghoul, Performance of basin type stepped solar still enhanced with superior design concepts, Desalination 435 (2018) 198-209

12. M.H.Sallami, T.Belkis, M.L.Aliouar, S.D.Meddour, H.Bouguettaia, K.Loudiyi, Improvement of solar still performance by covering absorber with blackened layers of sponge, Groundwater for Sustainable Development, Volume 5, 2017, 111-117

13. V.V.Cheboxarov, B.A.Yakimovich, L.M.Abd Ali, F.M.Al-Rufee, An Offshore Wind-Power-Based Water Desalination Complex as a Response to an Emergency in Water Supply to Northern Crimea Applied Solar Energy, 2019, vol. 55, pp. 260-264

14. Mohammed Shadi S.Abujazar, S. Fatihah, A.E.Kabeel, Sewater desalination using inclined stepped solar still with copper trays in a wet tropical climate, Desalination 423 (2017) 141-148

15. Mehrnaz Naroei , Faramarz Sarhaddi, Fatemeh Sobhnamayan, Efficiency of a photovoltaic thermal stepped solar still : Experimental and numerical analysis, Desalination 441 (2018) 87-95

16. Nancy Medina-Herrera, Salvador Tututi-Avila, Arturo JimenezGutierrez, Juanv GabrielvSegovia-Hernandez, Optimal design of a multi-product reactive distillation system for silanes production, Computer \& Chemical Energy, Vomule 105, 2017, 132-141

17. A.E.Kabeel, Mohammed Abdelgaied, Emad M.S. El-Said, Study of a solar-driven membrane distillation system: Evaporative cooling effect on performance enhancement, Renewable Energy, Volume 106, 2017 192-200

18. Lan Xiao, Run Shi, Shuang-Ying Wu, Zhi-Li Chen, Performance study on a photovoltaic thermal stepped solar still with a bottom channel, Desalination 471 (2019) 114-129

19. Zine Saddi, Ahmed Rahmani, Salah Lachtar, Hamou Soualmi, Performance evaluation of a new stepped solar still under the desert climatic conditions, Energy Conversion and Management 171 (2018) $1749-1760$ 
20. Y.A.F.El-Samadony, Wael M.El-Maghlany, A.E.Kabeel, Influence of glass cover inclination angle on radiation heat transfer rate within stepped solar still, Desalination, Volume 384, 2016, 68-77

21. A.Alaudeen, K.Johnson, P.Ganasundar, A.Syed Abuthahir, K.Srithar, Study on stepped type basin in a solar still, Journal of King Saud University - Engineering Sciences (2014) 26,176-183

22. Moh'd A.Al-Nimr, Suhil M. Kiwan, SamerTalafha, Hybrid solar-wind water distillation system, Desalination, Volume 395, 2016, 33-40

23. A.Ahsan, M.Imteaz, U.A.Thomas, M.Azmi, A.Rahman, N.N.Nik Daud, Parameters affecting the performance of a low cost solar still, Applied Energy 114 (2014) 924-930

24. Z.M.Omara, A.E.Kabeel, M.M.Younes, Enhancing the stepped solar still performance using internal reflectors, Desalination 314 (2013) 67-72

25. V.Sivakumar, E.Ganapathy Sundaram, Improvement techniques of solar still efficiency: A review, Renewable and Sustainable Energy Reviews 28 (2013) 246-264

26. A.E.Kabeel, A.Khalil, Z.M.Omara, M.M.Younes, Theoretical and experimental parametric study of modified stepped solar still, Desalination 289 (2012) 12-20

27. Aayush Kaushal, Varun, Solar Stills: A review, Renewable and Sustainable Energy Reviews 14 (2010) 446-453

28. V.Velmurugan, K.J.Naveen Kumar, T.Noorul Haq, K.Srithar, Performance analysis in stepped solar still for effluent desalination, Energy 34 (2009) 1179-1186

29. Ajay K. Manna, Mou Sen, Andrew R. Martin, Parimal Pal, Removal of arsenic from contaminated groundwater by solar-driven membrane distillation, Environmental Pollution,Volume 158, 2010, 805-811

30. Joachim Koschikowski, Marcel Weighaus, Matthias Rommel, Solar thermal-driven desalination plants based on membrane distillation, Desalination, Volume 156, Issues 1-3, 2003, 295-304

31. Tiwari GN, Vimal Dimri, Arvind Chel, Parametric study of an active and passive solar distillation system; Energy and exergy analysis, Desalination 2009;242:1-18

32. Tiwari GN, Tiwari AK. Solar distillation practice for water desalination systems. New Delhi; Anamaya Publishers; 2008

33. O.O.Badran, M.M.Abu-Khader "Evaluating thermal performance of a single slope solar still” Heat Mass Transfer (2007) 43:985-99 